\title{
Структурні зміни мікроциркуляторного русла дванадцятипалої кишки при обтураційному холестазі
}

\begin{abstract}
Мета роботи: морфологічно вивчити особливості ремоделювання судин мікроциркуляторного русла дванадцятипалої кишки при тривалому обтураційному холестазі.

Матеріали і методи. Морфологічно досліджено особливості ремоделювання судин мікроциркуляторного русла дванадцятипалої кишки при тривалому обтураційному холестазі, який моделювали перев’язкою загальної жовчної протоки. Мікроциркуляторне русло дванадцятипалої кишки досліджувалося за методом В. В. Купріянова через 3, 7, 14 та 28 діб змодельованого обтураційного холестазу.

Результати досліджень та їх обговорення. Проведеними дослідженнями встановлено, що обтураційний холестаз призводить до вираженого ремоделювання мікроциркуляторного русла дванадцятипалої кишки. На ранніх стадіях змодельованої патології виникає спазм приносних судин гемомікроциркуляторного русла та розширення закапілярних венул та венул, збільшення їх щільності. На 14 та 28 доби обтураційний холестаз ускладнюється розширенням лімфатичних та венозних судин мікроциркуляторного русла, зменшенням кількості гемокапілярів, гіпоксією, дистрофічними, некробіотичними, інфільтративними та склеротичними процесами у стінці дванадцятипалої кишки.
\end{abstract}

Ключові слова: обтураційний холестаз; дванадцятипала кишка; мікроциркуляторне русло.

Постановка проблеми і аналіз останніх досліджень та їх публікацій. Механічна жовтяниця (обтураційний холестаз) нерідко зустрічається у клінічній практиці і $є$ важливим ускладненням патологій органів гепатопанкреатобіліарної системи. Поширеність обтураційного холестазу, труднощі його діагностики, корекції та профілактики, незадоволеність клініцистів результатами його лікування поглиблюють актуальність даної медичної та соціальної проблеми [1, 2, 3]. При цьому невирішеними залишається низка питань. В останній час дослідники підвищену увагу звертають на кровопостачання органів шлунково-кишкового тракту при їхніх ураженнях та після оперативних втручань на них. Відомо, що дванадцятипала кишка має загальний кровоносний, лімфатичний та інерваційний зв’язок з органами, що іiї оточують виходячи з цього можна прийти до твердження, що патологічні процеси, а також різні оперативні втручання, що проводять на цих органах, без сумніву, повинні викликати зміни у мікроциркуляторному руслі дванадцятипалої кишки і змінювати її функціональний стан.

Мета роботи: морфологічно вивчити особливості ремоделювання судин мікроциркуляторного русла дванадцятипалої кишки при тривалому обтураційному холестазі.

Матеріали і методи. Морфологічними методами досліджено мікроциркуляторне русло дванадцятипалої кишки 25 свиней-самців в'єтнамської породи, які були поділені на 5 груп. 1-ша група (контрольна) нараховувала 5 тварин, 2-га - 5 свиней з 3-добовим обтураційним холестазом, 3-тя 5 тварин з 7-добовим обтураційним холестазом, 4-та - 5 свиней з 14-добовим обтураційним холестазом, 5-та - 5 тварин з 28-добовим обтураційним холестазом, який моделювали перев' язкою загальної жовчної протоки [4]. Усі маніпуляції та евтаназію дослідних свиней проводили з дотриманням основних принципів роботи з експериментальними тваринами відповідно до положення “Європейської конвенції про захист хребетних тварин, які використовуються для експериментальних та інших наукових цілей” (Страсбург, 1986 р.), “Загальних етичних принципів експериментів на тваринах”, ухвалених першим національним конгресом з біоетики (Київ, 2001 р.), а також Закону України "Про захист тварин від жорстокого поводження” (від 21.02.2006) [5]. Мікроциркуляторне русло дванадцятипалої кишки виявляли імпрегнацією сріблом за методом В. В. Купріянова [6, 7]. Проводилися також гістологічні дослідження стінки дванадцятипалої кишки. При цьому мікротомні зрізи дванадцятипалої кишки фарбували гематоксилінеозином за Ван-Гізон, Маллорі, Вейгертом, толуїдиновим синім [6, 7].

Результати досліджень та їх обговорення. При змодельованій обтураційній жовтяниці вже на 3 добу від початку екперименту відзначалися морфологічні прояви розладів органної гемодина- 
міки дванадцятипалої кишки. Останні характеризувалися венозним повнокрів'ям, спастичним станом стінок дрібних артерій та артеріальних судин гемомікроциркуляторного русла дванадцятипалої кишки. Артеріоли, передкапілярні артеріоли та гемокапіляри при цьому з нерівномірним просвітом, спазмовані, звивисті, закапілярні венули і венули нерівномірно розширені, місцями виражено дилатовані. У тканинах стінки дванадцятипалої кишки відмічалися виражені паравазальні і стромальні набряки (рис. 1). Спостерігалися осередки, де щільність мікросудин гемомікроциркуляторного русла на одиницю площі мала тенденцію до збільшення.

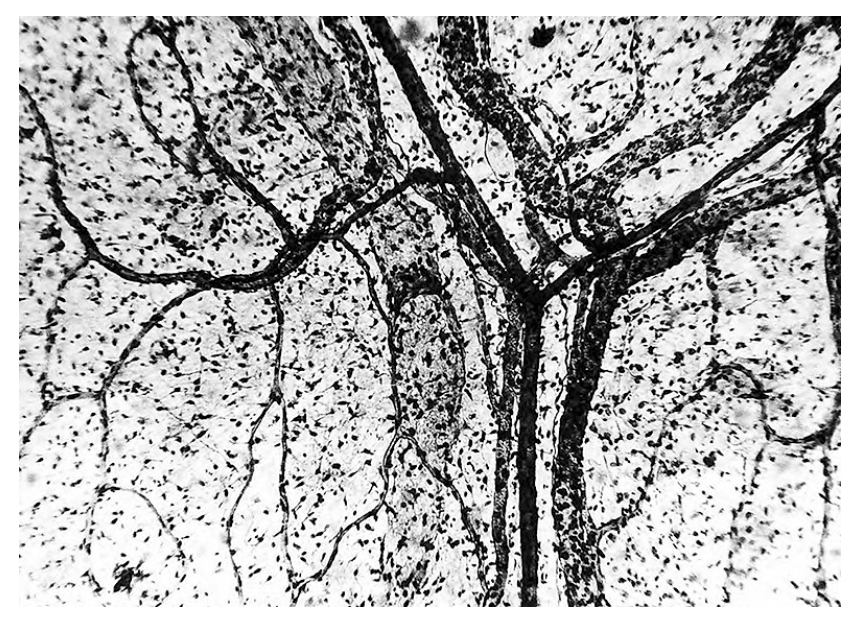

Рис. 1. Мікросудини дванадцятипалої кишки на 3-тю добу обтураційного холестазу. Імпрегнація сріблом за В. В. Купріяновим. х 200

При тижневому обтураційному холестазі в мікроциркуляторному руслі дванадцятипалої кишки виявлено дилатацію гемокапілярів, закапілярних венул, венул, а також лімфатичних судин. Закапілярні венули та венули виражено розширені, місцями варикозно змінені та обтуровані. Варто вказати, що аналогічну тенденцію до розширення мали венозні судини у всіх оболонках дванадцятипалої кишки (рис. 2).

Гістологічно на цей термін спостерігається повнокрів'я венозних мікросудин дванадцятипалої кишки, виражений стромальний та периваскулярний набряки, а також розволокнення та дезорганізація сполучнотканинних елементів. В деяких судинах десквамація окремих ендоцеліолитів. В слизовій та м'язовій оболонках інколи виявлялися безсудинні зони, дистрофічні та інфільтративні процеси.

Аналогічні явища встановлено при вивченні особливостей структурної перебудови мікроцир-

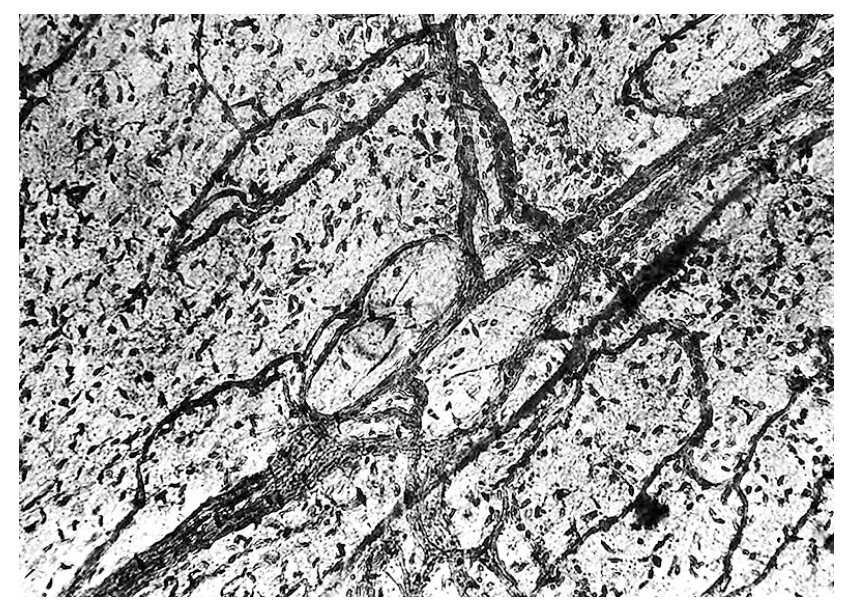

Рис. 2. Спазм артеріол, передкапілярних артеріол, розширення гемокапілярів та венозних мікросудин, безсудинні зони у дванадцятипалій кишці на 7-му добу обтураційного холестазу. Імпрегнація сріблом за В. В. Купріяновим. х 160

куляторного русла в слизовій, м’язовій оболонках та підслизовому прошарку досліджуваного органа на 14-ту добу обтураційного холестазу. Спостерігається дилатація вен, деякі з них деформовані, мають покручену форму з різним діаметром просвіту. Спостерігається домінування в мікроциркуляторному руслі венозних судин над артеріальними. Мали місце нерівномірність просвіту та виражена покрученість закапілярних венул та венул (рис. 3). Дані зміни мікроциркуляторного русла сприяють сповільненню кровотоку, депонуванню крові, порушенню дренажної функції вен та виникненню гіпоксії у тканинах досліджуваного органа.

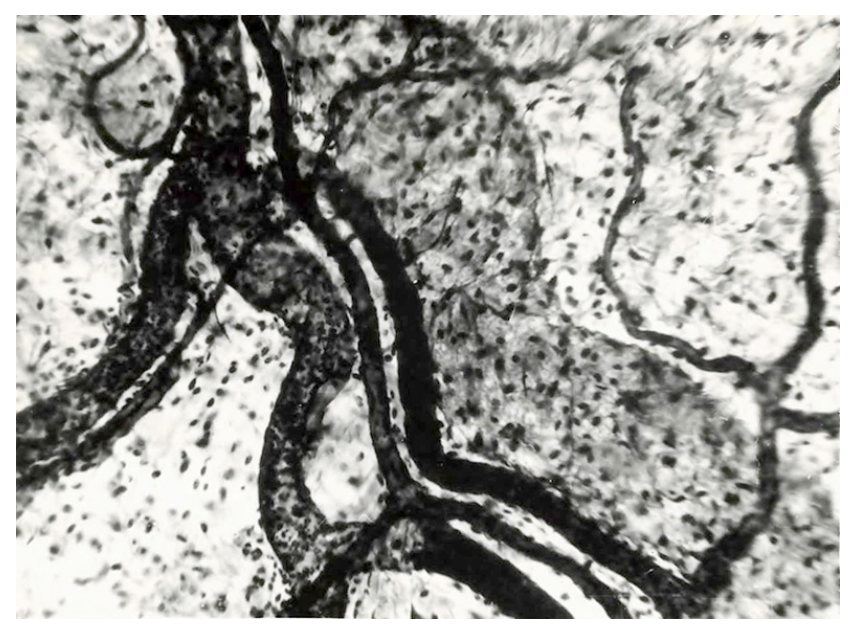

Рис. 3. Розширення венозних та лімфатичних судин, паравазальний і стромальний набряк, безсудинні зони у дванадцятипалій кишці на 14-ту добу обтураційного холестазу. Імпрегнація сріблом за В. В. Купріяновим. $\mathrm{x} 200$ 
У цих патологічних умовах суттєво зменшилася щільність капілярів, що вказувало на істотне погіршення кровообігу дванадцятипалої кишки. Гістологічно в кровоносних судинах спостерігається розширення, фрагментація еластичних мембран, а також зустрічаються атрофічні зміни. Останні охоплювали в основному невеликі групи гладком'язових волокон і еластичні волокна. Мали місце явища міоеластофіброзу.

Дослідження мікроциркуляторного русла дванадцятипалої кишки з 28-денним обтураційним холестазом свідчать, що зміни у всіх його ланках продовжували наростати. При цьому суттєво збільшувалося розширення обмінної (гемокапілярів) та венозної ланок (закапілярних венул та венул) гемомікроциркуляторного русла, лімфатичних судин. Більш вираженими були паравазальні та стромальні набряки у стінці досліджуваного органа. Зустрічалися осередки з некротичними змінами стінок мікросудин, їх обтурацією, вираженими безсудинними зонами (рис. 4). Кількість гемокапілярів суттєво зменшувалася, спостерігалася виражена дефор-

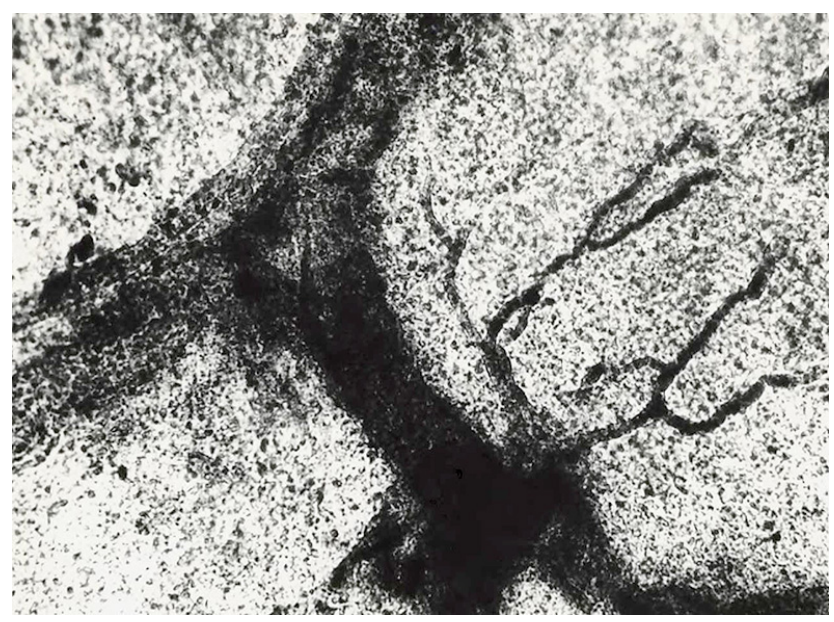

Рис. 4. Некроз стінки мікросудин дванадцятипалої кишки на 28-му добу обтураційного холестазу. Імпрегнація сріблом за В. В. Купріяновим. х 200

\section{СПИСОК ЛІТЕРАТУРИ}

1. Гнатюк М. С. Особливості структурної перебудови судин гемомікроциркуляторного русла дванадцятипалої кишки при обтураційному холестазі / М. С. Гнатюк, Л. В. Татарчук, С. О. Грабчак // Здобутки клінічної і експериментальної медицини. 2016. - № 4. - С. 36-39.

2. Пилипчук В. І. Варіанти операційних втручань на жовчовивідних протоках при хронічному панкреатиті з ознаками біліарної гіпертензії / В. І. Пилипчук // Шпитальна хірургія. 2016. - № 2. - C. 27-31.

3. Sobazstiano P. Pathophysiology of chronic damage / P. Sobazstiano, F. di Molat // Acute and Chronic Pancreatitis, Turin: Editioni Minerva modica. - 2013. - P. 63-69. 4. Пат. мація, нерівномірність просвіту, вогниша стазів та тромбозів у досліджуваних структурах. Структурні зміни у судинах мікроциркуляторного русла дванадцятипалої кишки призводили до гіпоксії, яка ускладнювалася дистрофічними, некробіотичними змінами епітеліоцитів, ендотеліоцитів, гладких міоцитів, осередками інфільтрації та склерозування у всіх оболонках досліджуваного органа (рис. 5).

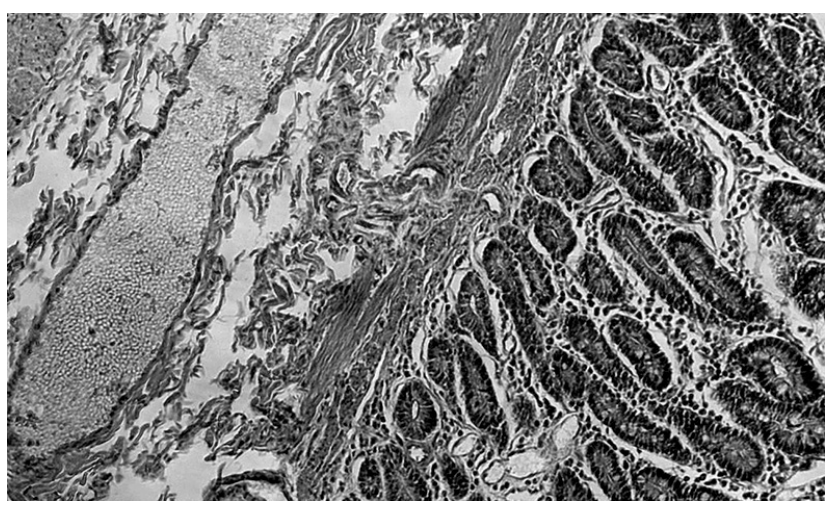

Рис. 5. Структурні зміни в слизовій оболонці, підслизовому прошарку та м'язовій оболонці дванадцятипалої кишки на 28-му добу обтураційного холестазу. Забарвлення гематоксиліном та еозином. х 160

Висновок. Обтураційний холестаз призводить до вираженого ремоделювання судин мікроциркуляторного русла. На ранніх стадіях структурні зміни при змодельованій патології характеризуються спазмом приносних мікросудин гемомікроциркуляторного русла та розширеннм його венозної стінки, збільшення їх щільності. На 14-ту та 28-му добу обтураційний холестаз ускладнюється вираженим розширенням лімфатичних та венозних структур мікроциркуляторного русла, зменшенням кількості гемокапілярів, гіпоксією, дистрофічними, некробіотичними, інфільтративними та склеротичними процесами у стінці дванадцятипалої кишки.

UA78273, МПК G 09B23/28(2006/01) Спосіб моделювання механічної жовтяниці / Гнатюк М. С. - № U201211327; заявл.01.10.2012; опубл.11.03.2013, Бюл. № 5.

5. Резников О. Г. Загальні етичні принципи експериментів на тваринах / О. Г. Резников // Ендокринологія. - 2003. - Т. 8, № 10. - С. 142-145.

6. Методика морфологічних досліджень / М. М. Багрій, В. А. Діброва, О. Г. Попадинець, М. І. Грищук. - Вінниця : Нова-Книга, 2008. - 318 с.

7. Основи гістологічної техніки і морфофункціональні методи дослідження у нормі та при патології / Л. П. Горальський, В. П. Хомич, О. І. Кононський. - Житомир : Полісся, 2011. - 288 с. 


\section{REFERENCES}

1. Hnatiuk, M.S., Tatarchuk, L.V., \& Hrabchak, S.O. (2016). Osoblyvosti strukturnoi perebudovy sudyn hemomikrotsyrkulyatornoho rusla dvanadtsiatypaloi kyshky pry obturatsiinomu kholestazi [The peculiarities of the structural reconstruction hemomicrocirculatory bed duodenum at obstructive cholestasis]. Zdobutky klinichnoi i eksperymentalnoi medytsyny - Achievements of Clinical and Experimental Medicine, 4, 36-40 [in Ukrainian].

2. Pylypchuk, V.I. (2016). Varianty operatsiinykh vtruchan na zhovchovyvidnykh protokakh pry khronichnomu pankreatyti z oznakamy biliarnoi hipertenzii [Options for surgery on the bile ducts in chronic pancreatitis with signs of biliary hypertension]. Shpytalna khirurhiia - Hospital Surgery, 2, 27-31 [in Ukrainian]. 3. Sobazstiano, P., \& di Molar, F. (2013). Pathophysiology of chronic damage. Acute and Chronic Pancreatitis. Turin: Editioni Minerva modica.
4. Patent UA78273, MPK G 09B23/28(2006/01). Sposib modeliuvannia mekhanichnoi zhovtianytsi [A method for modeling mechanical jaundice]. M.S. Hnatiuk - No U201211327; zaiavl. 01.10.2012; opubl.11.03.2013, Bul. No. 5 [in Ukrainian].

5. Reznykov, O.H. (2003). Zahalni etychni pryntsypy eksperymentiv na tvarynakh [General ethical principles of experiments on animals]. Endokrynolohiia - Endocrinology, 8, 1, 142-145 [in Ukrainian].

6. Bahrii, M.M., Dibrova, V.A., Popadynets, O.H., \& Hrychuk, M.I. (2008). Metodyka morfolohichnykh doslidzhen [Methods of morphological studies]. Vinnytsia: Nova-Knyha [in Ukrainian]. 7. Horalskyi, L.P, Khomych, V.P., \& Konopskyi, O.I. (2011). Osnovy histolohichnoi tekhniky i morfofunktsionalni metody doslidzhennia u normi ta pry patolohii [Fundamentals of histological technique and morphofunctional methods of research in normal and pathology]. Zhytomyr: Polissia [in Ukrainian].

Отримано 08.10.2019

\section{STRUCTURAL CHANGES OF THE MICROCIRCULATORY BED OF THE DUODENUM AT THE OBSTRUCTIVE CHOLESTASIS}

\begin{abstract}
The aim of the work: to study morphologically the features of vascular remodeling of the microcirculatory bed of the duodenum at prolonged obstructive cholestasis.

Materials and Methods. Features of vascular remodeling of the microcirculatory bed of the duodenum at prolonged obstructive cholestasis were investigated morphologically. Obstructive cholestasis was modeled by the ligation of the common bile duct. The microcirculatory bed of the duodenum was examined by the method of V. V. Kupriyanov after 3, 7, 14 and 28 days of simulated obstructive cholestasis. Results and Discussion. Studies have shown that obstructive cholestasis leads to marked remodeling of the microcirculatory bed of the duodenum. In the early stages of the simulated pathology, there is a spasm of the arterial vessels of the hemomicrocirculatory bed and expansion of the capillary venules and venules, increasing their density. At 14 and 28 days, obstructive cholestasis is complicated by the enlargement of the lymphatic and venous vessels of the microcirculatory bed, the decrease in the number of hemocapillaries, hypoxia, dystrophic, necrobiotic, infiltrative and sclerotic processes in the duodenal wall.
\end{abstract}

Key words: obstructive cholestasis, duodenum, microcirculatory bed.

Тернопольский национальный медицинский университет имени И. Я. Горбачевского МОЗ Украины

\section{СТРУКТУРНЫЕ ИЗМЕНЕНИЯ МИКРОЦИРКУЛЯТОРНОГО РУС.ЛА ДВЕНАДЦАТИПЕРСТНОЙ КИШКИ ПРИ ОБТУРАЦИОННОМ ХОЛЕСТАЗЕ}

\footnotetext{
Цель работы: морфологически изучить особенности ремоделирования сосудов микроциркуляторного русла двенадцятиперстной кишки при длительном обтурационном холестазе.

Материалы и методы. Морфологически исследованы особенности ремоделирования сосудов микроциркуляторного русла двенадцатиперстной кишки при длительном обтурационном холестазе, который моделировали перевязкой общего желчного протока. Микроциркуляторное русло двенадцатиперстной кишки исследовалось методом В. В. Куприянова через 3, 7, 14 и 28 суток смоделированного обтурационного холестаза.

Результаты исследований и их обсуждение. Проведенными исследованиями установлено, что обтурационный холестаз приводит к выраженному ремоделированию микроциркуляторного русла двенадцатиперстной кишки. На ранних стадиях смоделированной патологии возникает спазм приносящих сосудов гемомикроциркуляторного русла и расширения закапиллярних венул и венул, увеличение их плотности. На 14 и 28 суток обтурационный холестаз осложняется расширением лимфатических и венозных сосудов микроциркуляторного русла, уменьшением количества гемокапилляров, гипоксией, дистрофическими, некробиотическими, инфильтративными и склеротическими процессами в стенке двенадцатиперстной кишки.
}

Ключевые слова: обтурационный холестаз; двенадцатиперстная кишка; микроциркуляторное русло. 